\title{
The Nebraska Center for Molecular Biology of Neurosensory Systems: A Collaborative COBRE Project
}

\author{
Shelley Smith
}

Professor of Pediatrics

Director, Human Molecular Genetics

Munroe Meyer Institute, University of Nebraska Medical Center

7 he National Center for Research Resources (NCRR) at the National Institutes of Health has developed the Institutional Development Award (IDeA)

1 program to enhance biomedical research where NIH funding has been in the lower tier. Twenty-three states and Puerto Rico qualify for IDeA programs, including Nebraska, Kansas, and Oklahoma in our region. The Centers for Biomedical Research Excellence (COBRE) program is one of these mechanisms. COBREs are each organized around a central scientific theme, and the growth of research in that area is facilitated in three ways: support of core facilities to serve as resources, support of individual research projects primarily for junior faculty, and development of a mentoring program to ensure that the research projects result in independent NIH funding. In addition to building a network of successful researchers within a COBRE, regional interaction of COBREs and other IDeA programs is encouraged.

In building the research researchers in the participating infrastructure of a state, a COBRE institutions. Thus, the Center can aid program has a particularly unique junior faculty in establishing an aspect: the research projects associated independent research program, and can with the center are generally junior also help make advanced technologies investigators who have not had previous available to researchers beyond the renewable NIH funding, and their projects are designed to be the basis of grant applications that are funded after 2 -3 years of Center support. When external funding starts, the projects rotate off Center funding and new projects take their place. The mentoring program provides advice to the investigators to help ensure that he projects are successful, and the core facilities provide technical support for the investigators as well as for other

Center.

The Nebraska Center for the Molecular Biology of Neurosensory Systems is built around the characterization of the molecular mechanisms controlling the development and maintenance of neurosensory functions, particularly vision and hearing. Neurosensory cells of the inner ear and retina are not replaced after damage or degeneration, so understanding of the regulation of 
their development and the mechanisms of their loss are important steps to the identification of potential avenues for intervention.

Currently, COBRE projects are funded for 5 years for the first phase, and are eligible to apply for a second 5-year phase. While the focus of the first phase is the support of new investigators, the purpose of the second phase is consolidation and strengthening of the Center, and more senior researchers can be supported in addition to junior investigators. Our Center is currently starting its second phase.

Administration of a multiinstitutional center

Our Center for Neurosensory Systems is a collaboration of 3 institutions in Omaha. The University of Nebraska Medical Center is the lead institution and is the primary site for the administrative and scientific cores and has research programs in retinal development and disorders. Creighton University has a longstanding program in the regulation of development of the auditory system, and Boys Town National Research Hospital has strengths in the identification and characterizations of genes causing hearing and vision loss, particularly Usher Syndrome. The administration of the center is handled by co-PIs from each institution and an Administrator who together comprise an Executive Committee (Table 1).

\section{Table 1: Executive Committee for the Center for Neurosensory Systems, Phase I}

PI: Shelley D. Smith, Ph.D., University of Nebraska Medical Center

Co-PI: Bernd Fritsch, Ph.D., Creighton University

Co-PI: Edward Walsh, Ph.D., Boys Town National Research Hospital

Administrator: Melanie Schrack, University of Nebraska Medical Center

Advisor: Kirk Beisel, Ph.D., Creighton University

Although a co-PI structure is not the typical structure for a COBRE program, we found this to be very advantageous in coordinating the support of the participating institutions. The Executive Committee manages the overall direction of the Center, overseeing the progress of the investigators on the research projects, reviewing the core facilities, and selecting new projects as the initial projects rotate off COBRE funding. The co-PIs also act as liaisons with the administrations of their institutions, to keep them informed of progress in the Center and ensure their support for the investigators and cores and for recruitment of additional faculty members with interests within the scope of the Center. The potential for pilot funding and mentoring as well as the presence of state-of-the-art core facilities can be effective recruitment tools, and the co-PIs are responsible for keeping administrators and department chairs aware of the strengths of the Center in building research.

COBRE projects also have an External Advisory Committee made up of individuals who have national and international standing in research 
related to the Center. Their guidance ensures that the research of the Center is at the forefront of the field, incorporating research questions and technologies that are current and competitive. The EAC for the Neurosensory Center is shown in Table 2. They review Center projects twice a year, in person at an annual $21 / 2$ day meeting in Omaha, and again in 6 months via e-mail. At the annual meeting, each project investigator presents a 15-minute summary of their project and progress, followed by a 5 -minute question period. New projects are also presented for approval for funding.

Table 2: External Advisory Committee, Center for Neurosensory Systems, Phase I

Robb Krumlauf, Ph.D., Stowers Institute for Medical Research, University of Kansas School of Medicine

Cynthia C. Morton, Ph.D., Harvard University and Brigham \& Women's Hospital

Suzanne L. Mansour, Ph.D., University of Utah

Kathryn Albers, Ph.D., University of Pittsburg

Guy Richardson, Ph.D., University of Sussex, UK

The next day, the committee meets with the co-PIs and the core directors to discuss the progress of the Center, and then meets with each investigator individually for at least 30 minutes to discuss their projects and give advice. On the third day, the EAC meets again with the co-PIs to present their evaluation of the Center and to start to draft their report. The meeting culminates in a seminar presented by one of the EAC members which is open to the entire research community of the 3 institutions and helps to publicize the interests of the Center. The EAC finalizes its report over the next month and sends it to the PI, who then distributes it to the investigators. The EAC designed a format for progress report from each of the project investigators for submission to them 6 months later. The committee member's evaluations of these reports are shared with each of the investigators, and both of the EAC reports are submitted to the NCRR with the annual progress report.

The structure of the EAC and its evaluations will be unchanged in Phase II of the Center for Neurosensory Systems, with the exception that Dr. Robb Krumlauf will rotate off the committee and will be replaced by Dr. Jane Johnson, University of Texas Southwestern Medical Center, Dallas, TX. One member each year will rotate off and be replaced, thus helping to maintain the continuity of guidance of the center, but also adding new input.

\section{Core Facilities}

Similar to other NIH Centers, the COBRE programs have an Administrative Core and several scientific cores. The cores for the Center for Neurosensory Systems are listed in Table 3. 
Table 3: Core Facilities

\begin{tabular}{|l|l|}
\hline Administration & $\begin{array}{l}\text { Director: Shelley D. Smith } \\
\text { Administrator: Melanie Schrack }\end{array}$ \\
\hline $\begin{array}{l}\text { Mouse Genome } \\
\text { Engineering }\end{array}$ & $\begin{array}{l}\text { Director: Michael Salbaum (years 1-3), Kay-Uwe Wagner } \\
\text { (years 4-5) Supervisor: Judith Stribley }\end{array}$ \\
\hline Molecular Phenotyping & $\begin{array}{l}\text { Director: Claudia Kappan, (years 1-3); Bernd Fritzsch } \\
\text { (year 4-5) Supervisor: Anita Jennings }\end{array}$ \\
\hline Gene Expression & Director: James Eudy \\
\hline
\end{tabular}

The Administrative core is based at UNMC and is responsible for the financial aspects of the Center and its subcontracts to Creighton University and Boys Town National Research Hospital. It also oversees the activities of the Center, including a monthly Journal Club, a seminar series, the annual meetings with the EAC, and a mentoring program.

The mentoring program is a vital part of a COBRE. Each of the junior faculty investigators has a primary mentor to give advice on their research and on their career development. The primary mentor should be a senior researcher who is familiar with the area of research but is not a primary collaborator, thus ensuring the independence of the junior faculty member. Primary mentors are expected to talk with the investigator at least once a month and to review manuscripts and grant proposals. To compensate for the amount of time that is anticipated, a mentor receives salary support from the Center, usually 10\% FTE. Several secondary mentors are also designated for each research project, and these individuals have more direct expertise the research project of the investigator. Secondary mentors may change as the requirements of the project progresses.

The co-PIs of the Center also act as mentors, and together with the mentors and scientific core directors, they advise the investigators on publications, presentations at national meetings and the annual EAC meeting, and grant applications. Mock study sections also help the investigators understand the grant review process. The mentor and the EAC members can also identify researchers and potential collaborators outside of Omaha, helping the junior faculty members network in their field of research. Funds from the Center also support travel of each investigator to one national meeting a year to present their research.

The 3 scientific cores provide specialized services that would generally be beyond the expertise and financial resources of an individual lab and cover the basic progression of research of the projects in our center. The Mouse Genome Engineering core provides a variety of mouse models, including transgenic, knock-out, and conditional knock-outs of specific genes, allowing the examination of in vivo function of a genetic system in development. The Molecular Phenotyping core supplies an analysis of normal development and the results of genetic changes at the histological level, with techniques such as antibody optimization and immunohistochemistry, in situ hybridization, apoptosis assays, competition experiments, double-label studies, and whole mount preparations. The Gene Expression core provides microarray expression analysis using standard or 
custom chips. By comparing changes in gene expression at different times in development or as a result of genetic changes, researchers can identify candidate genes and assess their effects on the expression of other genes, thus highlighting genetic regulatory networks.

\section{Research Projects}

COBRE programs are designed to support several research projects lasting for 2-3 years. Our Center supported 4-5 projects at about $\$ 150,000$ per year. We also developed a funding mechanism to allow new investigators to conduct seed projects, generally $\$ 15,000-\$ 25,000$ per year, to determine the feasibility of a proposal for full project funding. This could be used to construct a mouse model, for example, to determine if the model is viable or has a phenotype that can be analyzed. We also provided bridge funding to lead into or supplement the externally funded project that is expected to result from the Center project. This funding was designed to complement the funded project and to help ensure renewal of the grant. The research projects supported by our Center in Phase I are given in Table 4, and the funding outcomes are shown in Table 5. The research projects in Phase I started out with a slightly broader

\section{Table 4: Research Projects}

\begin{tabular}{|l|l|l|}
\hline Investigator & Position and Institution & Title of Research Project \\
\hline Laura Hansen, Ph.D. & $\begin{array}{l}\text { Associate Professor, Biomedical } \\
\text { Sciences, Creighton University } \\
\text { School of Medicine }\end{array}$ & $\begin{array}{l}\text { Role of EGFR and erbB2 in the } \\
\text { regulation of skin innervation }\end{array}$ \\
\hline $\begin{array}{l}\text { Garrett Soukup, } \\
\text { Ph.D. }\end{array}$ & $\begin{array}{l}\text { Associate Professor, Biomedical } \\
\text { Sciences, Creighton University } \\
\text { School of Medicine }\end{array}$ & $\begin{array}{l}\text { MicroRNA regulation of } \\
\text { neurosensory development }\end{array}$ \\
\hline $\begin{array}{l}\text { Kristen Drescher, } \\
\text { Ph.D. }\end{array}$ & $\begin{array}{l}\text { Associate Professor, Medical } \\
\text { Microbiology and Immunology, } \\
\text { Creighton University }\end{array}$ & $\begin{array}{l}\text { Role of Neuregulins in Myelin } \\
\text { Repair in the CNS and PNS }\end{array}$ \\
\hline $\begin{array}{l}\text { Janee Gelineau-van } \\
\text { Waes, D.V.M, Ph.D. } \\
\text { Bssistant Professor, Genetics, Cell }\end{array}$ & $\begin{array}{l}\text { Role of Microphthalmia- } \\
\text { associated Transcription Factor } \\
\text { (Mitf) in Development of the } \\
\text { Retinal Pigment Epithelium (RPE) } \\
\text { and Inner Ear (stria vascularis) }\end{array}$ \\
\hline $\begin{array}{l}\text { Yunxia Lundberg, } \\
\text { Ph.D. }\end{array}$ & $\begin{array}{l}\text { Staff Scientist, Boys Town National } \\
\text { Research Hospital }\end{array}$ & $\begin{array}{l}\text { Formation and Regulation of } \\
\text { Otoconia }\end{array}$ \\
\hline Neena Haider, Ph.D. & $\begin{array}{l}\text { Assistant Professor, Department of } \\
\text { Genetics, Cell Biology \& Anatomy, } \\
\text { UNMC }\end{array}$ & $\begin{array}{l}\text { Functional characterization } \\
\text { ofNr2e3 in the developing and } \\
\text { adult photoreceptor cells }\end{array}$ \\
\hline $\begin{array}{l}\text { Dr. Sonia Rocha- } \\
\text { Sanchez, Ph.D. }\end{array}$ & $\begin{array}{l}\text { Assistant Professor, Oral Biology, } \\
\text { Creighton University School of } \\
\text { Dentistry }\end{array}$ & $\begin{array}{l}\text { The role of the E2F2 modulation } \\
\text { of Rb1 in cochlear hair cells and } \\
\text { supporting cells to mediate hair } \\
\text { cell regeneration }\end{array}$ \\
\hline $\begin{array}{l}\text { You-Wei Peng, M.D., } \\
\text { Ph.D. }\end{array}$ & $\begin{array}{l}\text { Staff Scientist, Boys Town National } \\
\text { Research Hospital }\end{array}$ & $\begin{array}{l}\text { Mechanisms of Retinal } \\
\text { Degeneration in Usher Syndrome } \\
\text { Type Ila }\end{array}$ \\
\hline $\begin{array}{l}\text { Sumitra } \\
\text { Bhattacharya, Ph.D. } \\
\text { Ossistant Professor, } \\
\text { Sciences, UNMC }\end{array}$ & $\begin{array}{l}\text { Characterization of retinal side- } \\
\text { population cells }\end{array}$ \\
\hline
\end{tabular}


interest on nervous system maintenance and development, including central and peripheral innervations. Subsequently, as the Center grew in numbers, the funded projects became more focused on development of the auditory and visual systems. The projects and a brief summary of their results are as follows:

Laura Hansen, Ph.D., Creighton University School of Medicine

$\underline{\text { Role of EGFR and erbB2 in the regulation of }}$ skin innervation

Epidermal growth factor receptor (EGFR) family members Erbb2/HER2, Erbb3/HER3, and Erbb4/HER4 are necessary for proper peripheral nervous system development. The role of EGFR in peripheral nervous system development, however, has never been investigated in vivo. Dr. Hansen's data demonstrated that EGFR is required for development of proper innervation to the dorsal skin in a cell autonomous manner through changes in the cell behavior of the DRG neurons.

Dr. Hansen also had a project in the COBRE-funded Nebraska Center for Cell Signaling, which was funded at the same time our Center was funded. At the first meeting with our EAC, it was recommended that in the second year her project should incorporate more cell signaling experiments, so funding was transferred entirely to the other COBRE.

Garrett Soukup, Ph.D., Creighton University School of Medicine

MicroRNA regulation of neurosensory development

MicroRNAs have been demonstrated to play fundamental roles in developmental processes including cell proliferation, fate specification and organ morphogenesis. This work established that miRNAs also influence the structural development of the inner ear. By determining the roles of miRNAs in normal ear development and function, the capacity of these genetic regulatory elements to guide specific cell fates and functions might eventually contribute to therapeutic strategies designed to stimulate hair cell regeneration and hearing restoration.

\section{Kristen Drescher, Ph.D., Creighton University School of Medicine \\ Role of Neuregulins in Myelin Repair in the CNS and PNS}

The purpose of this study was to investigate the genetic response to infection to determine which pathways mediate protective responses. To accomplish these studies, TMEVinduced models of demylination were modified to precisely identify where demylination first occurs. Using this model, the effects of conditional knockouts of the genes erbB2 and EGRF were tested individually and together.

Janee Gelineau-van Waes, D.V.M, Ph.D., University of Nebraska Medical Center

Role of Microphthalmia-associated Transcription Factor (Mitf) in Development of the Retinal Pigment Epithelium (RPE) and $\underline{\text { Inner Ear (stria vascularis) }}$

Although mutations in the Microphthalmia-Associated

Transcription Factor (MITF) are known to cause retinal disorders and sensorineural hearing loss in humans and mice, the signaling pathways involved have not been characterized. This research demonstrated that Mift may regulate iron homeostasis leading to the hypothesis that retinal damage is due in part to oxidative stress. This led 
to two tests of therapies; restriction of dietary iron to pregnant dams carrying normal and Mift vit embryos, and the ability of transplanted hematopoetic stem cells to replace the damaged RPE. Since excess iron accumulation has been implicated in several neurodegenerative diseases as well as retinal degeneration, this research could have clinical implications beyond the effects of MITF mutation.

Yunxia Lundberg, Ph.D., Boys Town National Research Hospital

Formation and Regulation of Otoconia

Over 6 million adults in the United States suffer from disorders of balance and dizziness, disorders which are particularly prevalent in the elderly and a significant cause of morbidity through falling and fractures. A significant cause of balance disorders is the degeneration and dislocation of otoconia, bio-crystals in the vestibular system. We generated a mutant mouse model in which the predominant mammalian otoconial protein, otoconin-90 (Oc90), is absent. The mutant mice had giant otoconia which were not attached to the sensory epithelium, resulting in poor balance and head-tilting. This suggests that perturbed otoconial proteins can lead to loose and dislocated otoconia, which is the cause of benign paroxysomal positional vertigo (BPPV), the most common form of dizziness.

Neena Haider, Ph.D., University of Nebraska Medical Center

Functional characterization of $\mathrm{Nr} 2 e 3$ in the developing and adult photoreceptor cells

The goal of this project is to understand the mechanisms through which photoreceptors are generated and maintained. The studies utilize the mutant mouse, $r d 7$, lacking the retina transcription factor $N r 2 e 3$, which is a model for the human Enhanced S Cone Syndrome characterized by a retinal degeneration and an increase in the function of blue cone cells. This project demonstrated that Nr2e3 is important in the development of rod and cone cells and in maintaining their function in the adult retina. Dr. Haider also identified 4 potential loci for modifier genes, with strong evidence that one of these is the Nr1d1 gene. Identification of modifiers will not only pinpoint proteins that interact with $N r 2 e 3$ pathways, but will highlight potential therapies.

Dr. Sonia Rocha-Sanchez, Ph.D., Creighton University School of Dentistry

The role of the E2F2 modulation of $R b 1$ in cochlear hair cells and supporting cells to mediate hair cell regeneration

$R b 1$ is required for normal hair cell (HC) cell cycle control, including differentiation and mitotic quiescence. Through control of $R b 1$ via modulation of the transcription factor E2F2, we propose to regulate the proliferation of supporting cells, creating the potential for their transdifferentiation into hair cells. During pilot funding, we produced a conditional knockout of E2F2 and mice carrying a conditional E2F2 transgene to allow us to study under- and overexpression of E2F2. Analysis of the knockout phenotype showed abnormal number and patterning of cochlear outer hair cells and abnormal innervation. We also performed a microarray analysis to identify potential downstream genes which could be additional targets for regulation. 


\section{You-Wei Peng, M.D., Ph.D., Boys Town National Research Hospital}

Mechanisms of Retinal Degeneration in Usher Syndrome Type Ila

Usher syndrome type IIa is the most common of the Usher syndromes, making it the single most important genetic cause of combined deafness and blindness in the world. We have evidence that the short isoform of usherin is a basement membrane protein that interacts with $\alpha 1 \beta 1$ integrin on retinal pigment epithelial cells, and some human USH2A mutations this interaction. We hypothesize that this interaction is essential for the retinal

Table 5: External Funding of Research Projects

\begin{tabular}{|l|c|l|l|}
\hline Investigator & $\begin{array}{l}\text { Years of } \\
\text { funding }\end{array}$ & $\begin{array}{l}\text { Grant awards } \\
\text { NIH/DOD/NSF }\end{array}$ & $\begin{array}{l}\text { Grant awards } \\
\text { Private foundations/other }\end{array}$ \\
\hline Hansen & 1 & R01 & $\begin{array}{l}\text { Health Futures Foundation, Nebraska } \\
\text { LB595 }\end{array}$ \\
\hline Soukup & 3 & $\begin{array}{l}\text { R01, EPSCOR } \\
\text { (NSF) }\end{array}$ & \\
\hline Drescher & 3 & DOD & Multiple Sclerosis Society \\
\hline $\begin{array}{l}\text { Gelineau-van } \\
\text { Waes }\end{array}$ & 3 & R21 & Retina Research Foundation \\
\hline $\begin{array}{l}\text { Lundberg } \\
\text { Haider }\end{array}$ & 3 & $\begin{array}{l}\text { R01, P50 (Deng, } \\
\text { PI) }\end{array}$ & Hope for Vision \\
\hline $\begin{array}{l}\text { Rocha- } \\
\text { Sanchez }\end{array}$ & 1 & R03 & Deafness Research Foundation \\
\hline Peng & 1 & & Research to Prevent Blindness \\
\hline Bhattacharya & 1 & &
\end{tabular}

pigment epithelium to function properly, with the resulting dysfunctional cell signaling directly affecting basement membrane metabolism and photoreceptor cell health, culminating in synaptic malformations and photoreceptor apoptosis. We have produced mouse models of integrin and usherin deficiency, and both have progressive retinal degeneration along with delayed translocation of transducin and arrestin in the rod photoreceptors in response to light/dark adaptation. Furthermore, it was demonstrated that increased light exposure produces more rapid photoreceptor degeneration in the mutant retinas.

\section{Sumitra Bhattacharya, Ph.D., University} of Nebraska Medical Center

Characterization of retinal sidepopulation cells

Identification and characterization of retinal progenitor cells offers the possibility to treat degenerative eye diseases using stem cell therapy. However, the success of this approach will largely depend upon the efficiency of enrichment of retinal stem cells and their maintenance ex vivo. Enrichment of neural stem cells is challenging for the lack of specific cell surface markers. We 
demonstrated that retinal stem cells can be enriched as a "side population" (SP) by Hoechst dye efflux assay, but this sorted population is still heterogeneous. This project will characterize retinal SP cells in terms of their molecular phenotype and regulation towards providing an approach to reproducibly enrich specific subpopulations of cells and predict the functional outcomes following their transplantation in animal models.

Dr. Rocha-Sanchez, Peng and Bhattacharya will continue their research projects for one more year into Phase II, and we have added two new projects:

David Nichols, Ph.D., Assoc. Professor, Biomedical Sciences, Creighton University School of Medicine

An analysis of the Lmx1a (Dreher) mutant inner ear

Our preliminary results show that members of the Dickkopf (Dkk) family of Wnt signaling modulators are altered in mice mutant for the LIM homeobox transcription factor, Lmx1a, suggesting that Lmx1a expression plays a role in the control of Wnt signaling. To verify this, we will compare the spatiotemporal distributions of Wnt's 2b, 4, 5a, $\mathrm{b}$ and 7a, plus those of Dkk's 1 and 2 in wildtype and Lmx1a mutant mouse inner ears. These would then be compared with alterations in the pattern of Wnt signaling in Lmx1a//TOPGAL mutant mice, accompanied by a molecular analysis of the genesis of the mutant stria vascularis and endolymphatic duct in the Lmx1a mutant. These studies will determine the role of Lmxla on the mechanism for endolymphatic homeostatis.

Michael Weston, Ph.D. Asst. Professor, Oral Biology and Biomedical Sciences, Creighton University School of Dentistry
Characterization of a MicroRNA misexpression model of age related deafness

MicroRNAs (miRNAs) are $\sim 22 \mathrm{nt}$ noncoding RNAs that inhibit expression of target mRNAs through complementary base pairing. Their functions are similar to transcription factors, but their interactions with know gene regulatory networks is unknown. To study the effects of miRNAs on auditory development, we have generated transgenic miR-183fam misexpression mouse lines, and one of these was found to show progressive loss of auditory hair cells. We hypothesize that this is due to perturbation of specific regulatory, structural and/or metabolic pathways, including the Notch signaling pathway ligand Jagged1 (Jag1) and a downstream effector transcription factor Sox2.

In the second year of Phase II, we anticipate adding two new projects which will be presented to the EAC for their approval. Taken together, the Center projects have common themes in the identification of the regulatory networks in development and maintenance of function of neurosensory systems, and the potential for therapy through regenerative methods, and we have reached a "critical mass" for exchange of ideas and techniques. Most importantly, all of the junior faculty investigators who participated in the COBRE program for more than 2 years have received federal funding.

\section{Regional Integration}

The National Center for Research Resources also funds other programs to enhance research in IDeA states. Two major programs serve as a pipeline to research institutions: the Science 
Education Partnership Awards (SEPA), which is designed to promote and enhance science education at elementary and secondary school levels, and the IDeA Networks of Biomedical Research Excellence (INBRE), which provides support for students, faculty, and research infrastructure for undergraduate institutions in partnership with research institutions. In Nebraska, a SEPA program headed by Dr. Maurice Godfrey at UNMC provides training for teachers in rural and tribal schools. It also interacts with a SEPA program at the University of NebraskaLincoln that is based in the Natural History museum there. These programs are designed to encourage students to go on to college programs in the sciences, and COBRE faculty have assisted in SEPA projects. The INBRE program headed by Dr. James Turpen at UNMC works with small colleges and tribal colleges and connects the faculty with research faculty at UNMC, UN$\mathrm{L}$, and Creighton University, and supports summer research opportunities for undergraduate students, encouraging them to consider graduate education. The INBRE program has interacted with the COBRE program by contributing to the funding of the Gene Expression Core, and many of the faculty of the COBRE and SEPA programs also participate in INBRE projects.

Regional collaboration between COBRE and INBRE programs is facilitated by meetings of PIs, administrators, and researchers in Nebraska, Kansas, Oklahoma, South Dakota, and North Dakota. The meeting is hosted by an institution from one of the states, giving them the opportunity to present their facility to other researchers in the region. Poster sessions allow all of the researchers to exchange information, and NCRR officials also attend to learn more about the programs and offer guidance. Through these meetings, our Center for Neurosensory Systems has found research goals in common with the Center for Epithelial Function at Kansas State University and the Center for Visual Neuroscience in South Dakota.

On alternate years, a national meeting is held in Bethesda for all COBRE and INBRE programs. This offers the opportunity to create collaborations on a national level, and also provides an opportunity for NCRR and NIH officials to update the PIs on new initiatives and priorities.

\section{Conclusion}

The Center for Neurosensory Systems has helped build an interactive group of researchers from 3 independent institutions, providing critical core facilities and bringing them together to produce the critical mass that supports discussion and growth of knowledge. The funding of research projects and provision of a mentoring program has resulted in independent funding for junior faculty who previously had not had that level of funding, helping our institutions "grow our own". Through additional support from other funding sources such as the INBRE or the University of Nebraska, the core facilities enhance the research infrastructure benefiting researchers at all 3 institutions. By networking with regional and national COBRE, INBRE, and SEPA researchers, the investment of the NCRR in IDeA states is leveraged further, so that the level of research quality is increased across the region.

\section{Acknowledgement}

This work is funded by NIH-NCRR P20 RR018788. 